\title{
The effect of preceding crops on damping-off of sugar beet and some ecological properties of the fungus Pythium Pringsh
}

\author{
MAURITZ VESTBERG \\ Department of Plant Pathology, University of Helsinki \\ SF-00710 HELSINKI, Finland
}

\begin{abstract}
The short- and long-term effects of preceding crops on damping-off of sugar beet were studied in pot trials in the glasshouse. Of the different types of plants studied, cereals most effectively decreased disease frequency. At the same time cereals on average also decreased the number of Pythium propagules in the soil, this being a short- and long-term effect. Legumes, on the other hand, seemed not to affect or even to increase damping-off as compared to continuously cultivated sugar beet. The influence on preceding crops on different soil types varied greatly.

The inoculum density or potential of Pythium generally correlated poorly with damping off of sugar beet. Nor did disease transformations cause any overall improvement of correlations.
\end{abstract}

Index Words: Preceding crops, damping-off, sugar beet, inoculum density, inoculum potential, Pythium

\section{Introduction}

Of the species of fungi causing damping-off of sugar beet, Aphanomyces spp. and Pythium spp. are reported to respond to cropping sequences. Preceding crops of leguminous plants have kept the level of damping-off constant or even increased it in relation to continuous sugar beet cropping. On the other hand, graminous crops have decreased damping-off (CoOns \& Kotila 1935, DeEms \&

Present address: Central Finland Research Station, Agricultural Research Centre Juntula, SF-41340 LAUKAA, Finland
Young 1956, Mumford 1968). ARndt and BEHR (1973) found no general relation between black leg and crop rotation or the frequency of beet crop. Infection by Pythium spp. was, however, more harmful on plots with narrow rotations and high concentration of sugar beet.

The ecological properties of soil fungi include for instance, inoculum density, inoculum potential and competitive saprophytic ability. These have been used to predict soil borne diseases.

The techniques for estimation of inoculum density of Pythium have been reviewed by 
Tsao (1970). These are baiting techniques in which plants or plant fragments are used for the detection of Pythium spp. These techniques are, however, more suitable for qualitative than for quantitative estimations. The soilplate technique (WARCUP 1950) and its modifications can be easily quantified. (RICCl et al. 1976, Vestberg 1985) and the statistical reliability of the results can be enhanced by using the MPN method (Maloy \& Alexander 1958). The techniques mentioned above detect Pythium species only by their saprophytic activity and do not distingwish pathogenic strains from saprophytic ones (Bоuнот 1979). The relationship between inoculum density and disease has been studied by several authors (Diamond \& Horsfall 1965, Baker 1971, Mitchell 1978, Gilligan 1983).

The inoculum potential of a pathogen has been defined in various ways. According to Diamond and Horsfall (1965), it can be defined in a broad sense as the resultant of the action of the environment, the vigor of the pathogen to establish an infection, the susceptibility of the host and the amount of inoculum present. Martinson (1963) defines the term as a function of inoculum density or intensity, available nutrient and genetic capacity of the organism. According to Bочнот (1979), the number of successful infections obtained in optimum environmental conditions on a standard susceptible host is in practice the only valid measure of inoculum potential. For reliable and replicable results in the estimation of inoculum potential the following criteria must be met (Bоuнот 1979):

1) Select a species susceptible to the parasite.

2) Use the plants at their most sensitive period.

3) Apply the naturally infested soil sample to the most sensitive part of the plant.

4) Standardize the environmental conditions so that the inoculum potential constantly induces maximum disease.

5) Quantify the techniques by progressively diluting the soil sample.

6) Determine optimal conditions for the highest selectivity, sensitivity and rapidity of the technique.
The sensitivity of the bioassays can be increased by adding selective substrates to the soil to increase the mass of inoculum. For Pythium spp. oat meal is applied to the soil (YARWOOD 1966). This increases the sensitivity of detection by at least 100 times (Bоuнот 1975a). Furthermore, a quantification factor can be introduced. Вочнот (1975b) diluted the test soil with sterile soil and obtained a partial linear relationship between the dilution rate and the amount of disease in the indicator plants. He used the linear part of the curvilinear graph to calculate the inoculum potential in the soil. He calculated an inoculum potential unit $\left(\mathrm{IPU}_{50}\right)$, which is defined as the minimum quantity $(\mathrm{g})$ of test soil necessary to induce $50 \%$ mortality in the plant population under the standard experimental conditions.

Several transformations have been suggested to produce a straight line from the curvilinear relationship between disease percentage and amount of inoculum (BAKER 1971). The most frequently used one is the multiple infection transformation (GrEGORY 1948) which takes into account the fact that the percentage of diseased plants observed in an experiment does not necessarily reflect the number of successful infectious. An individual plant may be invaded by a pathogen many times, but would be recorded only once as being diseased. Other possible transformations are the logarithmic probability (FISHER \& Yates 1967) and the log-log (Diamond \& Horsfall 1965, BaKer et al. 1967) transformations.

Damping-off is a serious problem in sugar beet cultivation in Finland (Vestberg et al. 1982). The most important causal agent of the disease is the fungus Pythium debaryanum auct. non Hesse. The common monocropping system is thought to be one of the main reasons for the disease. In 1982, experiments were started to investigate the effect of preceding crops on damping-off of sugar beet and especially on the ecological properties of Pythium spp. This paper presents the results of pot experiments in the glasshouse and climate chamber. 
Table 1. Species and varieties of crops used in the study of short-term effects of interupting crops in sugar beet monoculture. Pot experiment in glass house.

\begin{tabular}{ll}
\hline Species & Variety \\
\hline Sugar beet & Monohill \\
Field bean & Mikko \\
Pea & Simo \\
Rape & Torch \\
Barley & Pokko \\
Spring wheat & Ruso \\
Oats & Tiitus \\
Red clover & Venla \\
Meadow fescue & Valto \\
Timothy & Tammisto \\
\hline
\end{tabular}

\section{Materials and methods}

\section{Short-term experiments}

The effect of 4-month cultivation of different crops (Table 1) on damping-off of sugar beet was studied in a very fine sand soil (from Laitila) and in a peat soil (from Janakkala). The experiment was repeated twice. It was carried out in a glasshouse at a nighttime temperature of $+18^{\circ} \mathrm{C}$ and a daytime temperature of $+20-+35^{\circ} \mathrm{C}$, depending on the time of the year and the influence of the sun. Black plastic pots of 3.51 size were used. At the end of the experiment above-ground parts of the plants were removed. The soil in each pot was thoroughly mixed and used for estimation of damping-off potential and Pythium inoculum density.

\section{Long-term experiment}

On March, 10, a crop rotation experiment was started in the glasshouse. Monocropping of sugar beet was compared with crop rotations with field bean, barley or grass as interrupting crops (Table 2). After 8 growing periods the experiment was finished on April 5, 1985.

The soils used were naturally infested with damping-off. The soils originated from Lai- tila (very fine sand), Janakkala (peat) and Salo (sandy clay). The soil was put in white plastic boxes $(40 \times 60 \times 35 \mathrm{~cm})$ with a $5 \mathrm{~cm}$ layer of crushed stone at the bottom. The soil layer was $25 \mathrm{~cm}$. The experiment was done in triplicate. All crops were fertilized in the same way before sowing with $60 \mathrm{~g} / \mathrm{m}^{2}$ of compound fertilizer ( $\left.9 \mathrm{~g} \mathrm{~N}, 12 \mathrm{~g} \mathrm{P}_{2} \mathrm{O}_{5}, 9 \mathrm{~g} \mathrm{~K}_{2} \mathrm{O}\right)$. Sugar beet, field bean and barley were sown in 4 rows per box. The grass was sown by a broadcast sowing technique. Weeding was done by hand. At the end of each growing period the above-ground parts of the plants were remowed and the uppest $15 \mathrm{~cm}$ of soil was turn around and prepared for the following growing period. After each growing period, small soil samples were collected from 3 spots in each box in triplicate. The nine subsamples were pooled and mixed thoroughly for determination of inoculum density of Pythium. The damping-off potential was estimated after the third and inoculum potential of Pythium after the seventh and eighth growing period.

The long-term experiment lasted more than three years. During that time, the seasonal variations in climatological conditions were considerable. In winter the temperature in the glasshouse was maintained at $+13-+14^{\circ} \mathrm{C}$ at night (8h) and at $+18-+20^{\circ} \mathrm{C}$ during daytime $(16 \mathrm{~h})$. In summer the glasshouse was not heated. Very high temperatures were recorded especially in June. Some climatological values in the glasshouse in December and June 198284 averaged as follows:

Decem- June
ber

Global radiation,

$\mathrm{MJ} / \mathrm{m}^{2}$

Highest temperature, $+{ }^{\circ} \mathrm{C}$ day $18-20 \quad 40-50$

Lowest temperature, $+{ }^{\circ} \mathrm{C}$ night $13-14 \quad 10-12$

Relative air humidity, $\%$ day $25-35 \quad 25-55$

Relative air humidity, $\%$ night 
Table 2. Crop rotation experiment in glasshouse.

\begin{tabular}{|c|c|c|c|c|c|c|}
\hline \multirow[b]{3}{*}{ Rotation } & \multirow{3}{*}{$\begin{array}{c}\% \text { of } \\
\text { sugar } \\
\text { beet in } \\
\text { rotation }\end{array}$} & & & & & \multirow{2}{*}{$\frac{\text { Growing period }}{\text { Crop }}$} \\
\hline & & & & & & \\
\hline & & $\begin{array}{c}1 . \\
10.3 .- \\
29.6 .1982\end{array}$ & $\begin{array}{l}2 . \\
8.7 .-\overline{2} \\
27.10 . \\
1982\end{array}$ & $\begin{array}{c}3 . \\
11.11 .1982- \\
20.3 .1983\end{array}$ & $\begin{array}{c}4 . \\
13.4 .- \\
15.8 .1983\end{array}$ & $\begin{array}{l}5 . \\
16.8 .1983- \\
23.2 .1984\end{array}$ \\
\hline 1. & 86 & sugar beet & sugar beet & sugar beet & sugar beet & fallow \\
\hline 2. & 29 & field bean & field bean & sugar beet & sugar beet & fallow \\
\hline 3. & 43 & field bean & sugar beet & field bean & sugar beet & fallow \\
\hline 4. & 29 & barley & barley & sugar beet & sugar beet & fallow \\
\hline 5. & 43 & barley & sugar beet & barley & sugar beet & fallow \\
\hline 6. & 43 & grass & sugar beet & grass & sugar beet & fallow \\
\hline 7. & 14 & grass & grass & grass & sugar beet & fallow \\
\hline
\end{tabular}

The global radiation was 42.6 times bigger in June than in December. The use of artificial lights in the glasshouse in winter lowered this difference until it was about 10 times higher.

\section{Assessment of damping-off potential}

For estimation of damping-off potential, untreated sugar beet seeds were sown in test soil which was then transferred to a climate chamber with $+15^{\circ} \mathrm{C}$ at night $(8 \mathrm{~h})$ and $+25^{\circ} \mathrm{C}$ by day $(16 \mathrm{~h})$. The pots were enclosed in plastic bags to maintain a high moisture level. Plant emergence and post-emergence damping-off were recorded.

\section{Assessment of Pythium inoculum density (ID)}

The number of Pythium propagules per gram of soil was determined as explained in a previous paper (Vestberg 1985). Small amounts of soil $(3000 \mathrm{mg}, 300 \mathrm{mg}, 30 \mathrm{mg}$, $3 \mathrm{mg}$ ) were introduced into water agar at $+42^{\circ} \mathrm{C}$, acidified by addition of citric acid. After solidification of the agar, round discs of $1 \mathrm{~cm}$ diameter were cut out and transferred to the Pythium selective Martin's agar (MARTIN 1950) to which benomyl and PCNB had been added (15 ppm). After 24 hours of incubation in the dark at $+15^{\circ} \mathrm{C}$, the agar plates were kept at laboratory temperatures for 4 days at normal light, whereafter growth of Pythium was recorded. The results were in- terpreted statistically according to the MPN method (Maloy \& Alexander 1958).

\section{Assessment of Pythium inoculum potential (IP)}

The inoculum potential of Pythium was estimated by the method of Вочнот (1975a, b). Sugar beet was used as bait instead of cucumber.

Surface sterilized sugar beet seeds were first pregerminated for $48 \mathrm{~h}$ at $+28^{\circ} \mathrm{C}$. Healthy germlings were transplanted to pots with a mixture of peat and sand (3:1), 10 seedlings per pot. The pots were then kept at $+25^{\circ} \mathrm{C}$ for 6 days, whereafter the seedlings were ready for inoculation. A dilution series $(0.1 \%, 0.3 \%$, $1 \%, 10 \%, 30 \%$ and $100 \%$ of test soil) of the air-dried and sieved test soil was made, using a steam sterilized peat-sand mixture (1:1) as diluent. Each level of the series was amended with oat meal, $20 \mathrm{~g} / \mathrm{l}$. The 8 -day-old sugar beet seedlings were inoculated by pouring $50 \mathrm{ml}$ of each mixture around the hypocotyls in 4 pots (about $1-\mathrm{cm}$ layer). The pots were adjusted to $70-90 \%$ of water holding capacity, thereafter incubated in the dark at $+15^{\circ} \mathrm{C}$ for $24 \mathrm{~h}$ before exposed to light (6 000 lux for $15 \mathrm{~h}$ per day) at $+18-+20^{\circ} \mathrm{C}$ for the next 5 days. The number of seedlings with dampingoff was then recorded.

A dose-response curve was drawn between the amount of test soil used (on a logarithmic 


\section{Results}

\section{Short-term effect of preceding crop}

Emergence and seedling health

Cultivating leguminous plants for 4 months lowered plant emergence of sugar beet as determined in the bioassay for damping-off potential (Fig. 1). This was true in the very fine sand as well as in the peat. Preceding crops of cereals and rape yielded a higher sugar beet emergence in the peat soil but kept in somewhat unchanged in the very fine sand. The preceding crop had a similar effect on the scale) and the incidence of disease. A straight line was drawn from the linear part of the curve and inoculum potential of the test soil was estimated as the minimum quantity ( $\mathrm{g}$ ) of soil necessary to kill $50 \%$ of sugar beet seedlings $\left(\mathrm{IPU}_{50}\right)$. Soil samples were compared by calculating the number of IPU $\mathrm{I}_{50}$ per gram of soil. number of healthy plants after the dampingoff period.

\section{Pythium inoculum density}

The numbers of propagules of Pythium per gram of soil ranged from less than 1 to 160 in the very fine sand and from 92 to 273 in

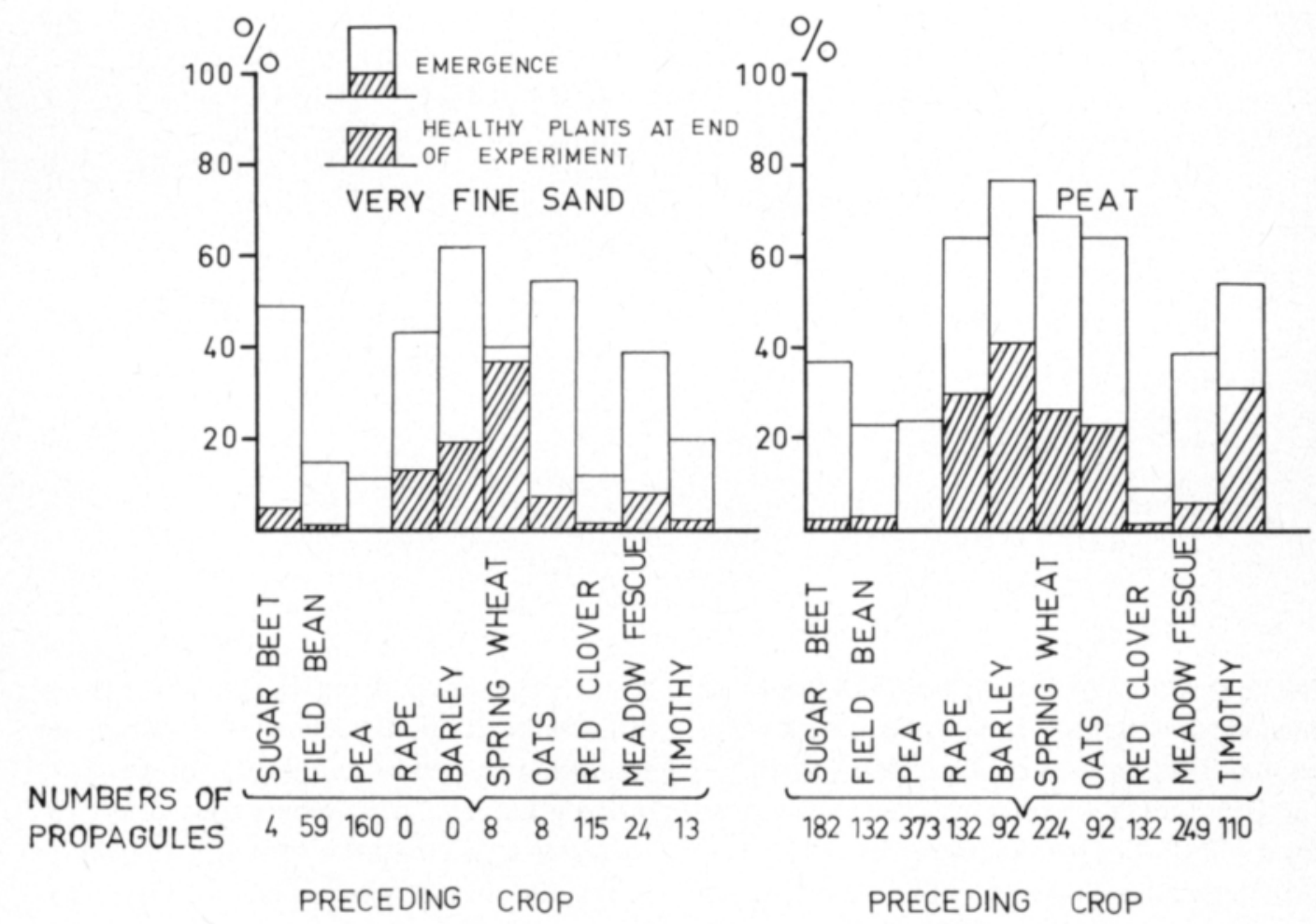

Fig. 1. Effect of one season (4 months) of cultivation of preceding crops on emergence and planth health of sugar beet seedlings. Two soil types. Figures below preceding crops indicate amount of Pythium propagules per gram of oven-dried soil. 
Table 3. Effect of preceding crops on emergence and post-emergence damping-off of sugar beet in growing periods 4 and 8 . Crop rotation experiment in glasshouse. Three soil types.

\section{A. GROWING PERIOD 4}

\begin{tabular}{|c|c|c|c|c|c|c|c|c|c|}
\hline \multirow[b]{2}{*}{ Preceding crops } & \multirow{2}{*}{$\begin{array}{l}\begin{array}{l}\text { Sugar beet } \\
\text { in rotation }\end{array} \\
\frac{\%}{0}\end{array}$} & \multicolumn{4}{|c|}{ Emergence, \% } & \multicolumn{4}{|c|}{ Post-emergence damping-off, $\%$} \\
\hline & & $\begin{array}{c}\text { Peat } \\
\text { soil }\end{array}$ & $\begin{array}{l}\text { Very fine } \\
\text { sand soil }\end{array}$ & $\begin{array}{c}\text { Sandy } \\
\text { clay }\end{array}$ & Mean & $\begin{array}{c}\text { Peat } \\
\text { soil }\end{array}$ & $\begin{array}{l}\text { Very fine } \\
\text { sand soil }\end{array}$ & $\begin{array}{c}\text { Sandy } \\
\text { clay }\end{array}$ & Mean \\
\hline S-S-S & 100 & $\begin{array}{l}77.0 \\
(=0)\end{array}$ & $\begin{array}{l}55.0 \\
(=0)\end{array}$ & $\begin{array}{r}83.0 \\
(=0)\end{array}$ & 71.7 & $\begin{array}{l}47.2 \\
(=0)\end{array}$ & $\begin{array}{r}35.6 \\
(=0)\end{array}$ & $\begin{array}{r}4.1 \\
(=0)\end{array}$ & 29.0 \\
\hline $\mathrm{Fb}-\mathrm{Fb}-\mathrm{S}$ & 33 & +19.0 & +2.3 & +1.3 & 79.2 & -21.8 & -13.0 & +1.1 & 17.7 \\
\hline $\mathrm{Fb}-\mathrm{S}-\mathrm{Fb}$ & 33 & +14.7 & +16.7 & -12.0 & 78.1 & -23.6 & -12.9 & +12.9 & 21.1 \\
\hline B-B-S & 33 & +20.3 & +33.3 & +15.7 & 94.8 & -35.2 & -1.3 & -2.5 & 16.0 \\
\hline B-S-B & 33 & +20.3 & +42.3 & -3.0 & 91.5 & -23.1 & -13.3 & -2.7 & 15.9 \\
\hline G-S-G & 33 & +8.7 & +30.7 & +2.7 & 85.7 & +3.9 & +5.5 & -0.7 & 31.9 \\
\hline G-G-G & 0 & +9.0 & +26.7 & +11.7 & 87.5 & -4.6 & -17.5 & -3.1 & 20.6 \\
\hline F-value & & 1.39 & 1.04 & 1.83 & & $2.84^{*}$ & 0.92 & 0.74 & \\
\hline $\mathrm{LSDt}_{0.05}$ & & & & & & 18.9 & & & \\
\hline
\end{tabular}

B. GROWING PERIOD 8

\begin{tabular}{|c|c|c|c|c|c|c|c|c|c|}
\hline \multirow[b]{2}{*}{ Preceding crops } & \multirow{2}{*}{$\begin{array}{l}\begin{array}{l}\text { Sugar beet } \\
\text { in rotation }\end{array} \\
\%\end{array}$} & \multicolumn{4}{|c|}{ Emergence, \% } & \multicolumn{4}{|c|}{ Post-emergence damping-off, $\%$} \\
\hline & & $\begin{array}{c}\text { Peat } \\
\text { soil }\end{array}$ & $\begin{array}{l}\text { Very fine } \\
\text { sand soil }\end{array}$ & $\begin{array}{c}\text { Sandy } \\
\text { clay }\end{array}$ & Mean & $\begin{array}{c}\text { Peat } \\
\text { soil }\end{array}$ & $\begin{array}{l}\text { Very fine } \\
\text { sand soil }\end{array}$ & $\begin{array}{c}\text { Sandy } \\
\text { clay }\end{array}$ & Mean \\
\hline S-S-S-S-F-S-S & 86 & $\begin{array}{r}60.3 \\
(=0)\end{array}$ & $\begin{array}{l}55.7 \\
(=0)\end{array}$ & $\begin{array}{l}59.7 \\
(=0)\end{array}$ & 58.6 & $\begin{array}{r}29.0 \\
(=0)\end{array}$ & $\begin{array}{r}38.4 \\
(=0)\end{array}$ & $\begin{array}{l}37.0 \\
(=0)\end{array}$ & 34.8 \\
\hline $\mathrm{Fb}-\mathrm{Fb}-\mathrm{S}-\mathrm{S}-\mathrm{F}-\mathrm{Fb}-\mathrm{Fb}$ & 29 & +1.4 & -15.7 & -9.4 & 51.0 & -9.3 & -28.4 & -24.7 & 14.0 \\
\hline Fb-S-Fb-S-F-Fb-S & 43 & +5.0 & -23.4 & +7.1 & 54.9 & -1.7 & -30.8 & +0.3 & 24.1 \\
\hline B-B-S-S-F-B-B & 29 & +3.4 & -12.4 & -13.0 & 51.2 & -19.3 & -5.8 & -28.7 & 16.9 \\
\hline B-S-B-S-F-B-S & 43 & +15.7 & -8.0 & +10.6 & 64.7 & -2.0 & -13.8 & -4.7 & 28.0 \\
\hline G-S-G-S-F-G-S & 43 & +6.0 & +7.4 & +10.3 & 66.2 & -13.7 & -6.4 & -12.7 & 23.9 \\
\hline G-G-G-S-F-G-G & 14 & -11.0 & +4.4 & +8.3 & 59.2 & -13.0 & -0.4 & -25.3 & 21.9 \\
\hline F-value & & 1.33 & $3.07^{*}$ & 1.12 & & 0.89 & 0.79 & $4.82^{* *}$ & \\
\hline $\mathrm{LSDt}_{0.05}$ & & & 23.8 & & & & & 20.5 & \\
\hline
\end{tabular}

Key:

$\mathrm{S}=$ Sugar beet

$\mathrm{Fb}=$ Field bean

$\mathrm{B}=$ Barley

$\mathrm{G}=$ Grass

$\mathrm{F}=$ Fallow

the peat soil. When sugar beet had been cultivated for 4 months, the propagules numbered 4 and 182 in the very fine sand soil and in the peat soil, respectively. Especially in the sand soil all the leguminous plants yielded significantly higher numbers of Pythium propagules, i.e. 59, 160 and 115 for field bean, pea and red clover, respectively. In the peat soil, no such clear effect was noticed, although pea raised the number from 182 to 373 . On the other hand, both field bean and red clover somewhat lowered the numbers of Pythium propagules. The grass plants used in the experiment also raised the content of Pythium propagules in many cases, but the effect was not as pronounced as with the leguminous plants. Cereals decreased the number of Pythium propagules on average (Fig. 1). 


\section{Long-term effects of preceding crops}

In order to study the long-term effect of several growing periods on damping-off of sugar beet, an experiment consisting of 8 growing periods was carried out in the glasshouse. During growing periods 4 and 8 sugar beet was grown throughout the experiment.

\section{Emergence and damping-off}

Continuous beet cultivation exhibited the lowest emergence in growing period 4 as compared to rotations with breaking crops of field bean, barley or grass (Table 3). Differences between soil types were relatively small. The rotation with two successive periods of barley yielded the highest emergence, $94.8 \%$, as compared to $71.7 \%$ for continuous beet. At the end of growing period 8 the emergence of sugar beet grown continuously exhibited an emergence of $58.6 \%$, but the rotations with field bean and one rotation with barley yielded even less emergence. Rotation every two years with grass yielded on average the best emergence, $66.2 \%$.

Beet monocropping showed a mean postemergence damping-off of $29 \%$ in growing period 4 and $34.8 \%$ in growing period 8 . All rotations exhibited less disease in both growing periods except for one grass rotation in growing period 4 . Barley most effectively decreased the disease frequency, especially in the peat soil. In this soil, field bean also decreased damping-off considerably (Table 3 ). Calculated for growing period 8 , the correlation coefficient between percentage of sugar beet in rotation and percentage of post-emergence damping-off was $r=0.841^{* *}$.

\section{Pythium inoculum density (ID)}

Pythium inoculum density, i.e. the number of Pythium propagules per gram of dry soil, was determined in growing periods $3-8$ over about two years. There were considerable variations in propagule densities between different growing periods (Fig. 2). A peak can

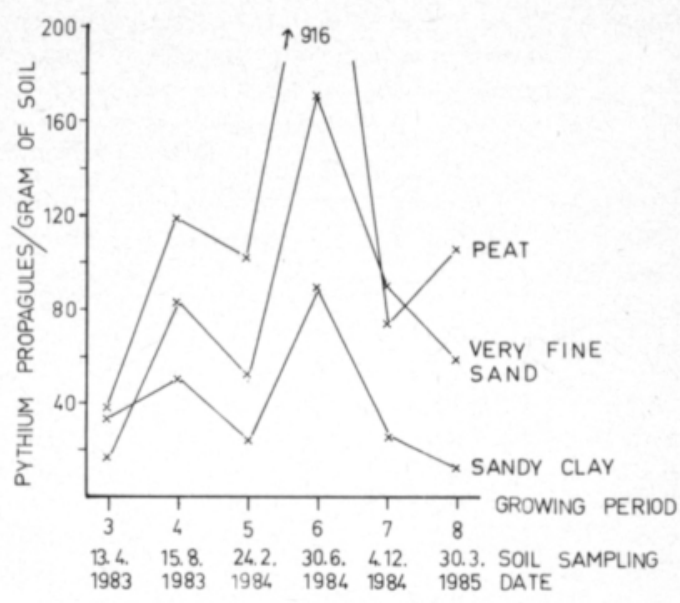

Fig. 2. Numbers of Pythium propagules per gram of oven-dried soil from growing periods $3-8$ in a glasshouse experiment with 8 growing periods. Three soil types.

be noticed especially in growing period 6, when propagule density was highest in all soil types. Fluctuations in propagule density were more pronounced in the peat soil than in the sandy clay soil.

Table 4 shows the numbers of Pythium propagules in plots with continuously cultivated sugar beet and in those with rotation. Crop rotations with field bean increased propagule density especially in the sandy clay and in the peat soil in most growing periods. In the very fine sand the effect was more variable. On average, rotations with barley decreased the propagule density somewhat, but there were grat variations. Rotation with every two years with grass increased the number of Pythium propagules in the peat and the sandy clay soil, but decreased in the very fine sand soil. The strongly grass dominated rotation had a decreasing effect in the peat and very fine sand soils, but the effect was negligible in the sandy clay soil.

\section{Pythium inoculum potential (IP)}

The inoculum potential (IP) of Pythium measured as the number of IPU $_{50}$ per gram of dry soil was determined in the glasshouse crop rotation experiment after the growing pe- 
Table 4. Effect of preceding crops on Pythium inoculum density estimated as the number of propagules per gram of oven-dried soil. Crop rotation experiment in glasshouse. Pythium ID estimations starting from growing period 3. Three soil types.

\begin{tabular}{|c|c|c|c|c|c|c|c|c|c|c|c|c|}
\hline \multirow[b]{2}{*}{$\begin{array}{l}\text { Growing } \\
\text { periods } \\
1-2\end{array}$} & \multicolumn{12}{|c|}{ Number of Pythium/g soil } \\
\hline & \multicolumn{2}{|r|}{$\begin{array}{l}\text { Growing } \\
\text { period } 3\end{array}$} & \multicolumn{2}{|r|}{$\begin{array}{l}\text { Growing } \\
\text { period } 4\end{array}$} & \multicolumn{2}{|r|}{$\begin{array}{l}\text { Growing } \\
\text { period } 5\end{array}$} & \multicolumn{2}{|r|}{$\begin{array}{l}\text { Growing } \\
\text { period } 6\end{array}$} & \multicolumn{2}{|r|}{$\begin{array}{l}\text { Growing } \\
\text { period } 7\end{array}$} & \multicolumn{2}{|r|}{$\begin{array}{l}\text { Growing } \\
\text { period } 8\end{array}$} \\
\hline \multicolumn{13}{|c|}{ PEAT } \\
\hline S-S & $\mathrm{S}$ & $28(=0)$ & $\mathrm{S}$ & $197(=0)$ & $\mathbf{F}$ & $77(=0)$ & $\mathrm{S}$ & $22(=0)$ & $\mathrm{S}$ & $105(=0)$ & $\mathrm{S}$ & $33 \quad(30)$ \\
\hline $\mathrm{Fb}-\mathrm{Fb}$ & $\mathrm{S}$ & +45 & $\mathrm{~S}$ & -134 & $\mathrm{~F}$ & +134 & $\mathrm{Fb}$ & +579 & $\mathrm{Fb}$ & +45 & $\mathrm{~S}$ & +173 \\
\hline $\mathrm{Fb}-\mathrm{S}$ & $\mathrm{Fb}$ & +46 & $\mathrm{~S}$ & +43 & $\mathrm{~F}$ & +109 & $\mathrm{Fb}$ & +2022 & $\mathrm{~S}$ & 0 & $\mathrm{~S}$ & +89 \\
\hline B-B & $\mathrm{S}$ & -11 & $\mathrm{~S}$ & -170 & $\mathbf{F}$ & -64 & $\mathrm{~S}$ & +5 & B & -96 & $\mathrm{~S}$ & -22 \\
\hline B-S & B & +2 & $\mathrm{~S}$ & -107 & $\mathbf{F}$ & -71 & B & +1 & $\mathrm{~S}$ & -92 & $\mathrm{~S}$ & -10 \\
\hline G-S & G & -24 & $\mathrm{~S}$ & -67 & $\mathbf{F}$ & +118 & $\mathrm{G}$ & +3628 & $\mathrm{~S}$ & +17 & $\mathrm{~S}$ & +298 \\
\hline G-G & G & 0 & $\mathrm{~S}$ & -51 & $\mathrm{~F}$ & -65 & G & +26 & G & -92 & $\mathrm{~S}$ & -15 \\
\hline \multicolumn{13}{|c|}{ VERY FINE SAND } \\
\hline S-S & $\mathrm{S}$ & $28(=0)$ & $\mathrm{S}$ & $130(=0)$ & $\mathrm{F}$ & $48(=0)$ & $\mathrm{S}$ & $31(=0)$ & $\mathrm{S}$ & $48(=0)$ & $\mathrm{S}$ & $59(=0)$ \\
\hline $\mathrm{Fb}-\mathrm{Fb}$ & $\mathrm{S}$ & -5 & $\mathrm{~S}$ & -51 & $\mathrm{~F}$ & +47 & $\mathrm{Fb}$ & +150 & $\mathrm{Fb}$ & +57 & $\mathrm{~S}$ & +178 \\
\hline $\mathrm{Fb}-\mathrm{S}$ & $\mathrm{Fb}$ & 0 & $\mathrm{~S}$ & +40 & $\mathrm{~F}$ & -17 & $\mathrm{Fb}$ & +329 & $\mathrm{~S}$ & +92 & $\mathrm{~S}$ & -24 \\
\hline B-B & $\mathrm{S}$ & -28 & $\mathrm{~S}$ & -90 & $\mathrm{~F}$ & -28 & B & +559 & B & -33 & $\mathrm{~S}$ & -43 \\
\hline B-S & B & -5 & $\mathrm{~S}$ & -94 & F & +11 & B & -19 & $\mathrm{~S}$ & +41 & $\mathrm{~S}$ & -39 \\
\hline G-S & G & -20 & $\mathrm{~S}$ & -14 & $\mathrm{~F}$ & -8 & G & -17 & $\mathrm{~S}$ & -15 & $\mathrm{~S}$ & -44 \\
\hline G-G & G & -24 & $\mathrm{~S}$ & -113 & $\mathrm{~F}$ & +11 & G & -31 & G & +158 & $\mathrm{~S}$ & -36 \\
\hline \multicolumn{13}{|c|}{ SANDY CLAY } \\
\hline S-S & $\mathrm{S}$ & $4(=0)$ & $\mathrm{S}$ & $4(=0)$ & $\mathrm{F}$ & $4(=0)$ & $\mathrm{S}$ & $40(=0)$ & $\mathrm{S}$ & $7(=0)$ & $\mathrm{S}$ & $2(=0)$ \\
\hline $\mathrm{Fb}-\mathrm{Fb}$ & $\mathrm{S}$ & +85 & $\mathrm{~S}$ & +121 & $\mathrm{~F}$ & +71 & $\mathrm{Fb}$ & +291 & $\mathrm{Fb}$ & +33 & $\mathrm{~S}$ & +21 \\
\hline $\mathrm{Fb}-\mathrm{S}$ & $\mathrm{Fb}$ & +99 & $\mathrm{~S}$ & +146 & $\mathrm{~F}$ & +53 & $\mathrm{Fb}$ & +5 & $\mathrm{~S}$ & +105 & $\mathrm{~S}$ & +25 \\
\hline B-B & $\mathrm{S}$ & 0 & $\mathrm{~S}$ & +25 & $\mathrm{~F}$ & -4 & B & -38 & B & -5 & $\mathrm{~S}$ & -1 \\
\hline B-S & B & 0 & $\mathrm{~S}$ & +3 & $\mathrm{~F}$ & +1 & B & -38 & $\mathrm{~S}$ & +2 & $\mathrm{~S}$ & 0 \\
\hline G-S & G & +45 & $\mathrm{~S}$ & +13 & $\mathrm{~F}$ & +3 & G & +17 & $\mathrm{~S}$ & +3 & $\mathrm{~S}$ & +18 \\
\hline G-G & G & 0 & $\mathrm{~S}$ & +15 & $\mathrm{~F}$ & -2 & G & +100 & G & -2 & $\mathrm{~S}$ & 0 \\
\hline
\end{tabular}

Key:

$\mathrm{S}=$ Sugar beet

$\mathrm{Fb}=$ Field bean

$\mathrm{B}=$ Barley

$\mathrm{G}=$ Grass

$\mathrm{F}=$ Fallow

riods 7 and 8 (Fig. 3). There were great variations in inoculum potential between growing periods and between the three soil types. Continuously cultivated sugar beet exhibited the highest IP in only one case, i.e. in the peat soil in growing period 8 . In the same soil in growing period 7 , the two rotations with field bean exhibited by far the highest IP. In the very fine sand soil, the field bean did not induce equally high IP as in the peat, but the highest IP was found in rotations with barley and grass. The third soil type, sandy clay, behaved in a somewhat similar manner as the peat. The highest IP was observed in rotations with field bean, especially in growing period 8 . In all three soil types, rotation with a high sequence of barley (no 4) exhibited lower IP of Pythium than did continuously cultivated sugar beet.

\section{Correlations between variables}

A significant negative correlation between Pythium ID and emergence of sugar beet seedlings could be noticed in a glasshouse experiment with 4-month cultivation of 10 different preceding crops. However, this was true only in one of two soil types in the above experiment (Table 5), i.e. the very fine sand soil. In the peat soil the correlation was not significant. At the end of the experiment the inoculum 


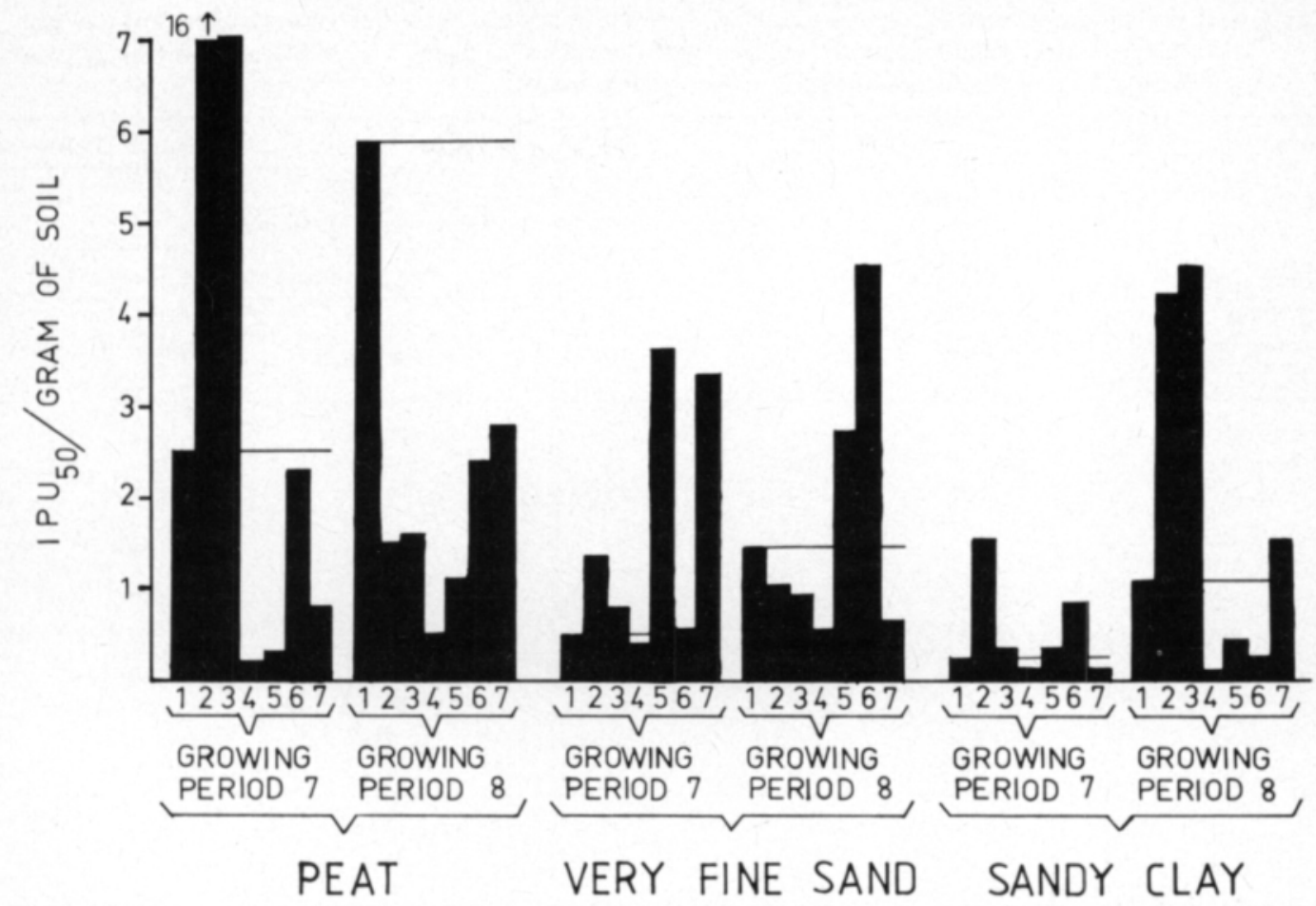

Fig. 3. Effect of preceding crops on inoculum potential of Pythium measured as the number of IPU $s_{0}$ per gram of oven-dried soil. Glasshouse experiment with 8 growing periods. Estimation of $\mathrm{IPU}_{50}$ in periods 7 and 8. Horizontal lines indicate levels of $\mathrm{IPU}_{5_{0}}$ in continuously cultivated sugar beet ( $\mathrm{nr}$ 1). For cropping sequences $2-7$ see Table 2 . Three soil types.

Table 5. Correlations between Pythium inoculum density and emergence, healthy plants at the end of the experiment and post-emergence damping-off. Pot trial in glasshouse with 10 preceding crops. Two soil types. Transformation of disease percentages.

\begin{tabular}{|c|c|c|c|c|c|c|c|}
\hline \multirow{5}{*}{$\begin{array}{l}\text { Pythium } \\
\text { inoculum } \\
\text { density }\end{array}$} & \multicolumn{7}{|c|}{ Correlation coefficients, $r(n=10)$} \\
\hline & \multirow{3}{*}{$\begin{array}{l}\text { Emer- } \\
\text { gence }\end{array}$} & \multirow{4}{*}{$\begin{array}{c}\text { Healthy } \\
\text { plants at the } \\
\text { end of exp. } \\
\%\end{array}$} & \multicolumn{5}{|c|}{ Post-emergence damping-off } \\
\hline & & & \multirow[b]{3}{*}{$\%(=y)$} & \multicolumn{4}{|c|}{ Transformations of $\%$} \\
\hline & & & & & $\log$ & & \\
\hline & $\%$ & & & $11-$ & $\underset{1-y}{-1}$ & Probit & Angular \\
\hline \multicolumn{8}{|l|}{$\begin{array}{l}\text { Very fine } \\
\text { sand soil: }\end{array}$} \\
\hline Number & $-0.781^{* * *}$ & -0.497 & $-0.556^{*}$ & $-0.555^{*}$ & -0.416 & -0.467 & -0.516 \\
\hline Log number & $-0.781^{* * *}$ & -0.481 & $-0.623^{*}$ & -0.619 & -0.495 & -0.371 & $-0.587^{*}$ \\
\hline \multicolumn{8}{|l|}{ Peat soil: } \\
\hline Number & -0.361 & -0.541 & 0.008 & -0.023 & 0.049 & 0.031 & 0.015 \\
\hline Log number & -0.365 & $-0.592^{*}$ & 0.060 & -0.021 & -0.276 & 0.022 & 0.009 \\
\hline
\end{tabular}

density of Pythium did not correlate with the percentage of healthy plants or the correlation was weak. This was also true of inoculum density and disease expressed as post-emergence damping-off. Transformations of disease percentages did not improve the results.

Table 6 shows the possible correlations between Pythium ID and emergence, post- 
Table 6. Correlations between Pythium inoculum density and emergence, post-emergence damping-off and percentage of not established sugar beet seedlings. Glasshouse experiment with different preceding crops. Three soil types. Transformations of disease percentages.

Correlation coefficients, $r(n=$

\begin{tabular}{|c|c|c|c|c|c|c|}
\hline \multirow{3}{*}{$\begin{array}{l}\text { Number of } \\
\text { Pythium } \\
\text { propagules/g } \\
\text { soil }\end{array}$} & \multirow[b]{3}{*}{$\begin{array}{c}\text { Seedling } \\
\text { emergence } \\
\%\end{array}$} & \multicolumn{5}{|c|}{ Post-emergence damping-off } \\
\hline & & \multirow[b]{2}{*}{$\%(=y)$} & \multicolumn{4}{|c|}{ Transformations } \\
\hline & & & $\operatorname{Ln} \frac{1}{1-y}$ & $\begin{array}{l}\log \\
\left(\ln \frac{1}{1-y}\right)\end{array}$ & $\begin{array}{l}\text { Probit } \\
\text { transf. }\end{array}$ & $\begin{array}{c}\text { Angular } \\
\text { transf. }\end{array}$ \\
\hline \multicolumn{7}{|l|}{ Peat soil: } \\
\hline Number & -0.507 & $-0.847^{* *}$ & $-0.732^{*}$ & $-0.798^{* *}$ & -0.580 & $-0.804^{* *}$ \\
\hline Log number & -0.272 & $-0.779^{* *}$ & $-0.792^{* *}$ & $-0.795^{* *}$ & $-0.798^{* *}$ & $-0.797^{* *}$ \\
\hline \multicolumn{7}{|l|}{$\begin{array}{l}\text { Very fine } \\
\text { sand soil }\end{array}$} \\
\hline Number & -0.628 & 0.336 & 0.368 & 0.040 & 0.061 & 0.259 \\
\hline Log number & -0.427 & 0.456 & 0.456 & 0.171 & 0.185 & 0.385 \\
\hline \multicolumn{7}{|l|}{$\begin{array}{l}\text { Sandy clay } \\
\text { soil: }\end{array}$} \\
\hline Number & -0.364 & 0.553 & 0.483 & 0.486 & 0.045 & 0.560 \\
\hline Log number & -0.05 & 0.434 & 0.503 & 0.417 & -0.322 & 0.459 \\
\hline
\end{tabular}

Table 7. Significance of correlations between Pythium ID and IP. Glasshouse experiment with differnet preceding crops. Pythium IP calculated from disease percentage and alternatively from transformations of percentage disease severity. Three soil types.

\begin{tabular}{|c|c|c|c|c|c|}
\hline \multirow[b]{5}{*}{$\begin{array}{l}\text { Pythium } \\
\text { inoculum } \\
\text { density }(=\mathrm{x})\end{array}$} & \multicolumn{5}{|c|}{ Significance of correlation coefficie } \\
\hline & \multicolumn{5}{|c|}{ Pythium inoculum potential, no of IPU } \\
\hline & \multicolumn{5}{|c|}{ Growing period 7} \\
\hline & \multirow{2}{*}{$\begin{array}{c}\mathrm{IPU}_{\mathrm{s}_{0}} \\
\text { calculated } \\
\text { from disease } \\
\text { percentages } \\
(=\mathrm{y})\end{array}$} & \multicolumn{4}{|c|}{ Transformations } \\
\hline & & $\operatorname{Ln} \frac{1}{1-y}$ & $\begin{array}{l}\log \\
\left(\ln \frac{1}{1-y}\right.\end{array}$ & $\begin{array}{l}\text { Probit } \\
\text { transf. }\end{array}$ & $\begin{array}{c}\text { Angular } \\
\text { transf. }\end{array}$ \\
\hline \multicolumn{6}{|l|}{ Peat soil: } \\
\hline Number & * & $* *$ & NS & ** & * \\
\hline Log number & $*$ & $*$ & NS & $*$ & NS \\
\hline \multicolumn{6}{|l|}{$\begin{array}{l}\text { Very fine } \\
\text { sand soil: }\end{array}$} \\
\hline Number & NS & ** & NS & * & * \\
\hline Log number & NS & $* *$ & NS & $*$ & NS \\
\hline \multicolumn{6}{|l|}{$\begin{array}{l}\text { Sandy clay } \\
\text { soil: }\end{array}$} \\
\hline Number & NS & NS & $* * *$ & * & $* *$ \\
\hline Log number & NS & $*$ & $* * *$ & $* * *$ & $* * *$ \\
\hline
\end{tabular}

emergence damping-off and not established seedlings of sugar beet in growing period 8 in a glasshouse crop rotation experiment. The significance of correlation coefficients varies in different soils. No significant correlation could be noticed between Pythium ID and seedling emergence. A moderate correlation occurred with post-emergence damping-off in the peat soil but not in the two other soils. On the other hand, when disease was measured 


\begin{tabular}{|c|c|c|c|c|}
\hline \multicolumn{5}{|c|}{$\begin{array}{l}\text { Not established seedlings ( }=100-\% \text { healthy } \\
\text { seedlings at end of experiment) }\end{array}$} \\
\hline \multirow[b]{2}{*}{$\%(=y)$} & \multicolumn{4}{|c|}{ Transformations } \\
\hline & $\operatorname{Ln} \frac{1}{1-y}$ & $\begin{array}{c}\log \\
\left(\ln \frac{1}{1-y}\right)\end{array}$ & $\begin{array}{l}\text { Probit } \\
\text { transf. }\end{array}$ & $\begin{array}{l}\text { Angular } \\
\text { transf. }\end{array}$ \\
\hline $\begin{array}{l}-0.659 \\
-0.692^{*}\end{array}$ & $\begin{array}{l}-0.643 \\
-0.696^{*}\end{array}$ & $\begin{array}{l}-0.651 \\
-0.743^{*}\end{array}$ & $\begin{array}{l}-0.649 \\
-0.754^{* *}\end{array}$ & $\begin{array}{l}-0.653 \\
-0.717^{*}\end{array}$ \\
\hline $\begin{array}{l}0.773^{* *} \\
0.669\end{array}$ & $\begin{array}{l}0.939^{* * *} \\
0.841^{* *}\end{array}$ & $\begin{array}{l}0.912^{* * *} \\
0.816^{* *}\end{array}$ & $\begin{array}{l}0.898^{* * *} \\
0.799^{* *}\end{array}$ & $\begin{array}{l}0.862^{* *} \\
0.764^{* *}\end{array}$ \\
\hline $0.758^{* *}$ & $0.727^{*}$ & $0.758^{* *}$ & $0.749^{*}$ & $0.758^{* *}$ \\
\hline $0.685^{*}$ & 0.622 & $0.674^{*}$ & 0.656 & $0.674^{*}$ \\
\hline
\end{tabular}

il

\begin{tabular}{|c|c|c|c|c|}
\hline \multicolumn{5}{|c|}{ Growing period 8} \\
\hline \multirow{2}{*}{$\begin{array}{c}\mathrm{IPU}_{\mathrm{s}} \\
\text { calculated } \\
\text { from disease } \\
\text { percentages } \\
\quad(=\mathrm{y})\end{array}$} & \multicolumn{4}{|c|}{ Transformations } \\
\hline & $\operatorname{Ln} \frac{1}{1-y}$ & $\begin{array}{c}\log \\
\left(\ln \frac{1}{1-y}\right)\end{array}$ & $\begin{array}{l}\text { Probit } \\
\text { transf. }\end{array}$ & $\begin{array}{l}\text { Angular } \\
\text { transf. }\end{array}$ \\
\hline NS & NS & NS & NS & NS \\
\hline NS & NS & NS & NS & NS \\
\hline NS & NS & NS & NS & NS \\
\hline NS & NS & NS & NS & NS \\
\hline * & NS & * & NS & $*$ \\
\hline${ }^{*}$ & NS & NS & NS & NS \\
\hline
\end{tabular}

as the percentage of not established seedlings ( $=100-\%$ healthy seedlings at end of experiment), the correlation to Pythium ID was highly significant in the very fine sand soil, moderately significant in the sandy clay, but not or very weakly significant in the peat soil. In peat the correlation was negative, but positive in the two other soils. No essential improvements of significance of correlation coefficients could be observed after transformations of disease percentages or use of log numbers of Pythium inoculum densities instead of aritmethical numbers.

The relationship between Pythium ID and IP, calculated on the basis of results obtained in a glasshouse crop rotation experiment, is shown in Table 7. On the whole, the significance of correlation coefficients was higher in growing period 7 than 8 . Transformations of disease percentages for calculation of $\mathrm{IPU}_{50}$ gave better correlation than the use of percentages. The Gregory and probit transformations proved the best.

\section{Discussion}

This paper presents some introductory experiments on the immediate and long-term effects of preceding crops on damping-off of sugar beet. The experiments were carried out in a glasshouse and growth chambers, and the results are not completely comparable to field conditions.

However, the effect of certain preceding crops was much the same as found by other authors (CoOns \& Kotila 1935, Deems \& Young 1956, Mumford 1968, Arndt \& Behr 1973). Leguminous plants such as pea, field bean or red clover tended to keep the level of damping-off unchanged or even to raise it as compared to continuously cultivated sugar beet. At the same time, these plants in most cases also increased the inoculum densities of Pythium in the soil, especially pea in the short run. Gramineous plants had an immediate opposite effect by increasing emergence and the numbers of healthy plants at the end of experiments and by decreasing the inoculum density of Pythium.

The effect of several growing periods of preceding crops was similar to that of one growing season, rotations with barley offering the best cropping system with respect to seed- 
ling emergence and damping-off. However, there were great variations in the results, depending on the soil type. Inoculum densities of Pythium measured during several growing periods also varied greatly, much depending on the date of soil sampling. The densities were higher in summer than in winter, which is presumably due to a temperature effect in the glasshouse (VestBerg 1984).

In Finland damping-off of sugar beet is mainly caused by the fungus Pythium debaryanum auct. non Hesse. The results presented here indicate that the effect of preceding crop on damping-off of sugar beet is much an effect on the pathogen Pythium. Leguminous crops are often attacked by Pythium spp. which are related to those attacking sugar beet (RoBerTsSON 1973, RuOKOLA 1979), suggesting that the leguminous crops can serve as nutrient and energy sources also for Pythium species on sugar beet. However, the great variation of experimental results, especially with respect to the soil type, indicate the importance of other factors than the pathogen Pythium. Preceding crops do, for instance, affect the soil microflora. This effect might be more or less pronounced after different crops and in different soil types.

There are many investigations on the quantitative relationship between inoculum density and soil borne diseases, eg. Pythium spp. (Mitchell 1978, Ferriss 1982), Rhizoctonia solani (VAN BRUGGEN et al. 1986), Fusarium spp. (Guy \& BAKer 1979), Phytophthora (Mitchell 1978). However, these experiments have usually been carried out under artificial controlled conditions in growth chambers or in glasshouses.

In the experiments presented here, in some cases inoculum density of Pythium correlated with seedling emergence or with dampingoff of sugar beet, and in other cases it did not. Unexpectedly, there occurred even significant negative correlations between inoculum density and damping-off in the very fine sand soil and also in the peat soil. On the whole, the present results seem to support the view of Diamond and Horsfall (1965), who claim that, only in exceptional cases is inoculum density of a pathogen in direct proportionality to the disease. Many authors use different transformations of disease percentages to obtain better correlations with inoculum density (Baker 1971, Ferriss 1982, Gilligan 1983). Bounot and JoAnNes (1978) compared in a material of more than 600 soil samples four mathematical transformations of disease percentages. In $80-90 \%$ the log-log and the probit-log transformations proved the best. In the present investigation there was no overall improvement of correlations between inoculum density and disease by the use of transformations, although in some cases this did happen. The material is, however, too small to draw any conclusions in this respect.

According to Вочнот (1979), the system inoculum potential - disease is the most appropriate for Pythium to calculate the risk of obtaining disease. In the present investigation, the IP of Pythium was estimated in growing periods 7 and 8 in a glass house crop rotation experiment. Although drastic changes in IP values were observed, IP did not correlate with seedling emergence or post-emergence damping-off in the experiment. The correlation between inoculum density and inoculum potential of Pythium showed some significance only in one of three soil types.

The variables estimated in this investigation, e.g. damping-off, Pythium ID and IP varied greatly. This can at least partly be explained by different seasonal conditions in the glasshouse. Although the basis of the crop rotation experiment was that all the growing periods would be comparable with each other, this was not the case in practise. In winter the temperature in the glasshouse was quite stable, but the light intensity was low, despite the use of artificial light. It is a well known fact that legumes (in this case field bean) suffer from light deficiency more than do e.g. grasses. In summer there was enough light, but there were great diurnal variations in temperature. These climatic conditions affect plants and microorganisms. 
Acknowledgements. I wish to express my warmest thanks to the head of the Department of Plant Pathology, Prof. Eeva Tapio, who by her encouragement and support made it possible to complete the experiments. She also read the manuscript as did Prof. Aarre Ylimäki and they both gave valuable suggestions. I am also very grateful to the Finnish Sugar Beet Research Centre for co-operation in the work on damping-off of sugar beet.

\section{References}

Arndt, R. \& Behr, L. 1973. Einfluß von Fruchtfolge und Anbaukonzentrationen auf die Auflaufkrankheiten der Zuckerrübe. Nachr.bl. Pflanzenschutzd. DDR 27: 53-57.

BAKER, R. 1971. Analyses involving inoculum density of soilborne plant pathogens in epidemiology. Phytopath. 61: 1280-1292.

BAKer, R., Maurer, G.L. \& Maurer, R.A. 1967. Ecology of plant pathogens in soil. Mathematical models and inoculum density. Phytopath. 57: 662-666.

Вочнот, D. 1975a. Recherches sur l' écologie des champignons parasites dans le sol. V Une technique sélective d'estimation du potentiel infectieux des sols, terreaux et substrates infestés par Pythium sp., études qualitatives. Ann. Phytopath. 7: 9-18.

- , 1975b. Recherches sur l écologie des champignons parasites dans le sol. VIII Quantification de la technique d'estimation du potentiel infectieux des sols, terreaux et substrates, infesteś par Pythium sp. Ann. Phytopath. 7: $147-154$.

-, 1979. Estimation of inoculum density and inoculum potential: Techniques and their value for disease prediction. In "Soil borne plant pathogens". Eds SCHIPPERS, B \& Gams, W., Academic Press, New York, 686 pp.

Coons, G.H. \& KotiLA, J.E. 1935. Influence of preceding crops on damping-off of sugar beets. Phytopath. 25: 13.

Deems, R.E. \& Young, H.C. 1956. Black roots of sugar beets as influenced by various cropping sequences and their associated mycofloras. J. Am. Sug. Beet Technol. 9: 33-43.

Diamond, A.E. \& Horsfall, J.G. 1965. The theory of inoculum. In "Ecology of soil-borne plant pathogens". Eds. BAKER, K.F. \& SNYDER, W.C., University of California Press, Berkeley, Los Angeles, 522 pp.

Ferriss, R.S. 1982. Relationship of infection and damping-off of şoybean to inoculum density of Pythium ultimum. Phytopath. 72: 1397-1403.

Fisher, R.A. \& Yates, F. 1957. Statistical tables for biological, agricultural and medical research. Oliver and Boyd Ltd., Edinburgh, 138 pp.

Gillıgan, C.A. 1983. Modeling of soilborne pathogens.
Ann. Rev. Phytopath. 21: 45-64.

Gregory, P.H. 1948. The multiple-infection transformation. Ann. Appl. Biol. 35: 412-417.

Maloy, O.D. \& Alexander, M. 1958. The most probable number for estimating populations of plant pathogenic organisms in the soil. Phytopath. 48: $126-128$.

Martin, J.P. 1950. Use of acid, rose bengal and streptomycin in the plate method for estimating soil fungi. Soil Sci. 69: 215-232.

MArtinson, C.A. 1963. Inoculum potential relationships of Rhizoctonia solani measured with soil microbiological sampling tubes. Phytopath. 53: 634-638.

Ricci, P., Toribio, J.A. \& Messiaen, C.M. 1976. I La dynamique des populations de Pythium dans les sols Maraîchers de Guadeloupe. Métodes d'étude. Ann. Phytopath. 8: 51-63.

Robertsson, G.I. 1973. Pathogenicity of Pythium spp. to seeds and seedling roots. New Zealand J. Agric. Res. 16: $367-372$.

RuокоLA, A.-L. 1979. II Fungus diseases of pea seeds and stands in Finland. Acta Agric. Scand. 29: 225233.

TsAo, P.H. 1970. Selective media for isolation of pathogenic fungi. Ann. Rev. Phytopath. 8: 157-186.

Vestberg, M. 1984. Damping-off of sugar beet in Finland. III Effect of temperature and disease forecasting. J. Agric. Sci. Fin. 56: 283-290.

- , 1985. Experiments on direct isolation of Pythium spp. from Finnish sugar beet soils. J. Agric. Sci. Fin. 57: 223-230.

-, Tahvonen, R., Raininko, K. \& Nuormala, N. 1982. Damping-off of sugar beet in Finland. I Causal agents and some factors affecing the disease. J. Agric. Sci. Fin. 54: 225-244.

WARCUP, J.H. 1950. The soil-plate method for isolation of fungi from soil. Nature 166: 117-118.

Yarwood, C.E. 1966. Detection of Pythium in soil. PI. Dis. Rep. 50: 791-792.

Ms received April 2, 1987 


\section{Esikasvin vaikutus sokerijuurikkaan taimipoltteeseen ja Pythium-sienen ekologisiin ominaisuuksiin}

\section{Mauritz Vestberg}

Kasvipatologian laitos, Helsingin yliopisto $00170 \mathrm{Helsin} k i$

Nykyinen osoite:

Keski-Suomen tutkimusasema, Maatalouden

tutkimuskeskus Juntula, 41340 Laukaa

Suomessa viljellään sokerijuurikasta yleisesti samalla pellolla vuodesta toiseen, mikä lienee eräs taimipoltteen yleistymisen syy. Viime vuosina on kuitenkin tutkittu yksipuolisen viljelyn katkaisemista sopivilla välikasveilla. Vuodesta 1982 alkaen esikasvin vaikutusta sokerijuurikkaan taimipoltteeseen on selvitetty sekä astia- ettă kenttäkokeissa. Koska Pythium debaryanum-sieni on taimipoltteen tärkein aiheuttaja Suomessa, on esikasvin vaikutusta tutkittu myös Pythium-sienen ekologisiin ominaisuuksiin, eli itiötiheyteen ja tautia aiheuttavaan kykyyn. Tämä kirjoitus käsittelee esikasvin sekä lyhyt- (1 kasvikausi) että pitkäaikaista (useita kasvukausia) vaikutusta taimipoltteeseen astiakokeissa.

Viljakasvit văhensivät taimipoltetta eniten. Tämä nä- kyi sekä lyhyt- että pitkäaikaisena vaikutuksena. Viljat vähensivät myös Pythium-sienen itiötiheyttä maassa. Palkokasveilla oli kuitenkin päinvastainen vaikutus. Jatkuvaan sokerijuurikkaaseen verrattuna ne pitivät taimipoltteen samalla tasolla tai jopa lisăsivăt sen esiintymistä. Nurmella oli kokeissa hyvin vaihteleva vaikutus eri maalajeilla. Nurmikasvit saattoivat lisătä taimipoltetta ja Pythium-sienen itiötiheyttä hyvin voimakkaasti.

Esikasvit aiheuttivat muutoksia Pythium-sienen itiötiheydessä ja tautia aiheuttavassa kyvyssä. Nämä ekologiset ominaisuudet olivat kuitenkin vain joissakin tapauksissa riippuvaisuussuhteessa taimipoltteeseen. Maalaji oli merkittävä vaihtelun lähde. 